\title{
Long-Term Unemployment in the Varieties of Capitalism
}

\author{
Alberto Chilosi*
}

\begin{abstract}
This paper considers how the different varieties of capitalism affect the rate of long-term unemployment. The liberal market variety, where employment protection is the lowest, presents lower rates of long-term unemployment than the continental European, or the Mediterranean varieties. In the latter both employment protection and long-term unemployment are the highest and labour market participation the lowest. But the social-democratic Scandinavian variety gets the best of both worlds: low rates of long-term unemployment, high rates of labour participation, lower degree of inequality, together with relatively high levels of employment protection. Low rates of long-term unemployment and high levels of labour participation are also produced by the far-Eastern Asian variety, but at the cost of a markedly dualistic labour market structure.
\end{abstract}

Keywords: Varieties of Capitalism, Long-term unemployment. Employment protection

JEL Classification: J64, P1

\section{Introduction}

The main object of the paper is to consider how employment protection leads to different long-term rates of unemployment in the different varieties of capitalism. In the varieties of capitalism literature at the centre stage of labour market performance is the aggregate rate of unemployment. ${ }^{1}$

But this is misleading: the real social and economic issue is not unemployment as such but long-term unemployment. Indeed, short-term unemployment can be seen as physiological to the functioning of the labour market, while long-term unemployment is uncontroversially pathological. This paper innovates, alongside a previous one centred on issues of corporate governance (Chilosi, 2012), by putting long-term unemployment instead of aggregate unemployment as such at the centre stage of the comparison between the labour market performance of different varieties of capitalism.

\footnotetext{
*Alberto Chilosi is at Department of Economics and Faculty of Political Sciences, University of Pisa, Pisa, Italy
} 


\section{Employee Protection and Representation, and the Varieties of Capitalism}

A priori we may think the different ways in which workers' interests are protected to be substitute to each other: for instance mandatory representation in corporate boards or in work councils as a substitute to collective trade unions rights or to individual employee rights. In reality rather than substitution complementarity applies, different economic and institutional traditions and different social and political values achieving different overall levels of employee protection. ${ }^{2}$

Labour market institutions, together with complementary ones relating to social policy and the economic role of the state, or the working of financial and commodity markets, allow to distinguish different varieties of capitalism. Following authors such as Hall and Soskice (2001), and Amable (2003) we may distinguish the following varieties of developed capitalist economies:
1. Liberal market
2. Continental European
3. Mediterranean European
4. Social-democratic Scandinavian
5. East Asian. ${ }^{3}$

\section{Long Term Unemployment and Labour Market Performance in the Varieties of Capitalism}

In the tables that follow we show labour market outcomes, and in particular rates of long-term unemployment, for the above varieties, as well as the degree of employment protection, as indicated by OECD's aggregate employment protection index (averages for the years 1991-2007): ${ }^{4}$

Table 1. Long -term unemployment, employment protection, and the varieties of capitalism: the liberal market, central European and Mediterranean European varieties ${ }^{\text {a) }}$.

\begin{tabular}{|l|c|c|c|c|c|}
\hline & $\begin{array}{c}\text { Long-term } \\
\text { unemployment rate }\end{array}$ & $\begin{array}{c}\text { Unemployment } \\
\text { rate }\end{array}$ & $\begin{array}{c}\text { Participation } \\
\text { rate }\end{array}$ & $\begin{array}{c}\text { Youth long-term } \\
\text { unemployment rate }\end{array}$ & $\begin{array}{c}\text { Employment } \\
\text { protection index }\end{array}$ \\
\hline USA & 0.5 & 5.4 & 66.1 & 0.6 & 0.21 \\
\hline UK & 2.2 & 6.7 & 61.4 & 2.7 & 0.66 \\
\hline Canada & 1.0 & 8.4 & 65.6 & 0.7 & 0.75 \\
\hline Australia & $2 . .0$ & 7.4 & 63.5 & 2.6 & 1.05 \\
\hline Ireland & 4.5 & 8.4 & 57.4 & 6 & 0.98 \\
\hline Average & $\mathbf{1 . 7}$ & $\mathbf{7 . 3}$ & $\mathbf{6 2 . 8}$ & $\mathbf{2 . 5}$ & $\mathbf{0 . 7 3}$ \\
\hline & & & & & 2.5 \\
\hline Germany & 4.2 & 8.6 & 58.5 & & 2.54 \\
\hline
\end{tabular}




\begin{tabular}{|c|c|c|c|c|c|}
\hline France & 3.8 & 10.3 & 55.3 & 5 & 3.01 \\
\hline Belgium & 4.5 & 8.2 & 51.1 & 6.6 & 2.52 \\
\hline Netherland & 2.2 & 4.8 & 61.4 & 0.6 & 2.4 \\
\hline Austria & 1.2 & 4.1 & 58.3 & 1.1 & 2.13 \\
\hline Average & 3.2 & 7.2 & 56.9 & 3.2 & 2.52- \\
\hline Italy & 5.8 & 9.8 & 48.1 & 15.8 & 2.69 \\
\hline Spain & 7.3 & 15.5 & 52.4 & 10.9 & 3.31 \\
\hline Greece & 5.1 & 9.6 & 52.1 & 13.3 & $3.27-$ \\
\hline Portugal & 2.5 & 5.9 & 60.7 & 10.9 & 3.67 \\
\hline Average & 5.2 & 10.2 & 53.3 & 12.7 & 3.24 \\
\hline
\end{tabular}

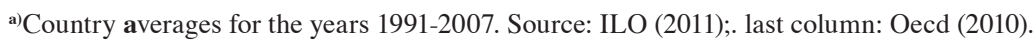

Table 2. Long-term unemployment, employment protection, and the varieties of capitalism: the liberal market, central European and Mediterranean European varieties ${ }^{\text {a) }}$.

\begin{tabular}{|c|c|c|c|c|c|}
\hline Country & $\begin{array}{c}\text { Long-term } \\
\text { unemployment rate }\end{array}$ & $\begin{array}{l}\text { Unemployment } \\
\text { rate }\end{array}$ & $\begin{array}{c}\text { Participation } \\
\text { rate }\end{array}$ & $\begin{array}{c}\text { Youth long-term } \\
\text { unemployment rate }\end{array}$ & $\begin{array}{c}\text { Employment } \\
\text { protection index }\end{array}$ \\
\hline Denmark & 1.5 & 6 & 66.1 & 0.8 & 1.71 \\
\hline Finland $^{5}$ & 2.9 & 10.8 & 61.7 & 1.9 & 2.08 \\
\hline Sweden & 1.7 & 7.1 & 64 & 2.3 & 2.44 \\
\hline Norway & 0.6 & 4.3 & 65.6 & 0.6 & 2.69 \\
\hline Average & 1.7 & 7.1 & 64.4 & 1.4 & 2.23 \\
\hline Japan & 1 & 3.9 & 62.4 & 1.3 & 1.58 \\
\hline Korea & 0.1 & 3.5 & 61.2 & 0.1 & 2.32 \\
\hline Taiwan & NA & 3.1 & NA & NA & NA \\
\hline Singapore & 0.1 & 3.7 & 65.4 & NA & NA \\
\hline Hong Kong & NA & 4.3 & 61.4 & NA & NA \\
\hline Average & & 3.7 & 62.6 & & \\
\hline
\end{tabular}

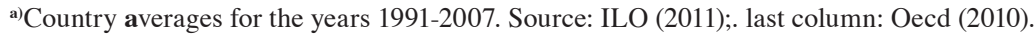

Table 3. The varieties of capitalism: resilience to the crisis. Average rates of longterm unemployment in the years 2008-2011 a)

\begin{tabular}{|l|c|l|c|l|c|l|c|l|c|}
\hline USA & 1.9 & Germany & 3.4 & Italy & 3.7 & Denmark & 1.1 & Japan & 1.6 \\
\hline UK $^{6}$ & 2.1 & France & 3.4 & Spain & 5.7 & Finland & 1.5 & Korea & 0.0 \\
\hline Canada & 0.8 & Belgium & 3.6 & Greece & 5.5 & Sweden & 1.1 & & \\
\hline Australia & 1.0 & Netherlands & 1.1 & Portugal & 5.3 & Norway & 0.3 & & \\
\hline Ireland & 5.0 & Austria & 1.0 & & & & & & \\
\hline Average & $\mathbf{2 . 2}$ & Average & $\mathbf{2 . 5}$ & Average & $\mathbf{5 . 1}$ & Average & $\mathbf{1 . 0}$ & Average & $\mathbf{0 . 8}$ \\
\hline
\end{tabular}

a) Source: ILO (2010) 
From the data reported in the tables above it turns out that, with the notable exception of the Scandinavian and Far Eastern varieties, wherever there is greater employment protection, long-term unemployment is on average higher, and the participation rate lower.

Looking at the individual countries we can see that there are two clear outliers: Ireland and Austria. Ireland has a long-term unemployment performance akin to that of the Central European and Mediterranean countries, notwithstanding a low level of employment protection. It is notable however that following favourable external factors as well as policy choices (such as centralized bargaining leading to wage moderation) its performance markedly improves since the half of the nineties ${ }^{7}$, leading to very low rates of long-term unemployment, comparable to those of the other liberal market economies, towards the end at the nineties and during the following decade until the crisis. Amable (2003, p. 173), contrary to Hall and Soskice, puts Ireland in the Central European variety. We have followed Hall and Soskice owing to Ireland's low index of employment protection and the Anglo-Saxon legal tradition common with the other economies of the group. Austria, whose institutions make it close the social-democratic Scandinavian model, has low level of long-term unemployment, together with a high level of employment protection. This applies to lesser extent also to the Netherlands. ${ }^{8}$ We have put France in the central European variety following Amable, but it is on the borderline: according to Hall and Soskice (p. 21) it belongs to the Mediterranean variety"(marked by a large agrarian sector and recent histories of extensive state intervention").

If we now turn to the aggregate rate of unemployment, we see that the differences between the different varieties are much smaller. For the liberal market, central European and Scandinavian varieties the difference is practically nought. The rate is about half in East Asia, and about one third higher in the Mediterranean variety. From the above data we may draw the conclusion that in the liberal market and Scandinavian varieties the labour market is on average markedly more dynamic than in the other ones, as borne by the implied higher rates of short-term unemployment (of course job to job transfers, another aspect of labour market dynamics, are not considered here). ${ }^{9}$ It had to be expected in fact that in the liberal market economies where layoffs (and thus hirings) are less difficult and costly short run unemployment to be higher. In the Scandinavian case leaving a job in order to look for a better one is less risky than wherever rates of long-term unemployment are higher, while unemployment subsidies are particularly generous, this should entail higher rates of voluntary separations and thus of short-term unemployment.

\section{The Special Scandinavian Case: The Best of Both Worlds?}

According to the above data the Scandinavian model produces the best of both worlds: high levels of labour market performance with low levels of long-term unemployment, as well as high levels of employment protection, together with comparatively greater equality (as shown in table 5 below). ${ }^{10}$ 
Table 5. Levels of inequality (Gini coefficients) and varieties of capitalism ${ }^{\mathrm{a}}$

\begin{tabular}{|l|l|l|l|l|l|l|l|l|l|}
\hline USA & 45 & Germany & 28.3 & Italy & 36 & Denmark & 23.2 & Japan & 38.1 \\
\hline UK & 36 & France & 26.7 & Spain & 34.7 & Finland & 26.9 & Korea & 35.8 \\
\hline Canada & 32.6 & Belgium & 33 & Greece & 35.1 & Sweden & 25 & Taiwan & NA \\
\hline Australia & 35.2 & Netherland & 30.9 & Portugal & 38,5 & Norway & 25.8 & Singapore & 42.5 \\
\hline Ireland & 34 & Austria & 31 & & & & & & \\
\hline Average & 36.6 & Average & 30 & Average & 36,1 & Average & 25,2 & Average & 38,8 \\
\hline
\end{tabular}

aSource: WorldFactbook 2007. The lower the value of the Gini coefficient the lower is inequality

How does the Scandinavian model produce its labour market remarkable outcomes? As explained by a group of authoritative Scandinavian economists (Andersen et al, 2007), the labour market institutions entail "high unionization, highly coordinated wage bargaining geared to wage compression, active labour market policies, and relatively generous unemployment benefits" (p. 40). Thus, social cohesion ${ }^{11}$ and centralized decision making bring about wage moderation, as the possible consequences of wage increases on aggregate employment are to some extent internalized. At the same time active labour market policies contribute to achieve low levels of incidence of long-term unemployment. ${ }^{12}$

\section{Is the Scandinavian Model Exportable?}

It seems unlikely that the Scandinavian model could be easily exportable elsewhere. It is certainly not exportable wherever the trade union movement is fragmented and subjected to the competition of "ultras" trade unions sharing the zero sum view of a class struggle ideology, leading to a wage push incompatible with relative price stability and full employment, or whenever trade unions are poised to the defence of specific sectoral interests rather than paying attention to overall workers' interests (including the unemployed). In general "economies at the extremes - with highly centralized or highly decentralized labour markets - had better employment records than those economies 'betwixt and between"” (Freeman, 1988, p. 65) ${ }^{13}$. Moreover, independently of the formal institutions, cooperative solutions as of the Scandinavian type are more difficult wherever, as is apparently the case in Mediterranean countries, important sections of public opinion and of the political class, as well of the trade union movement, share the popular economic fallacies expounded in the appendix. The correspondent cultural background may be reflected not only in the extent of labour protection granted by the formal legal framework, but also in the way in which it finds actual judicial application. Finally "Nordic countries are small and ethnically homogenous ... Ethnic homogeneity is conducive to the emergence of trust, the key ingredient in "social capital", which is widely believed to improve the efficiency of society by facilitating coordinated action. In fact, the level of trust is higher in the Nordic countries (and the Netherlands) than elsewhere according to 
available indicators" (Andersen et al., 2007, p. 39). But these peculiarities of the Scandinavian (or "Nordic") social model are challenged by the recent processes of massive immigration (ibidem).

\section{What about the South-East Asian Model?}

It is based on a dualistic labour market solution: the core employees enjoy protection of their job legally or implicitly while the workers in the secondary market are subjected to a high degree of flexibility and much lower pay, functioning as a buffer stock. In particular there is high supply elasticity of the female component of the labour force, with a high propensity to retire from the labour market in case of downward employment pressure, as related to more traditional family values. In Japan "the majority of employees such as female employees, part-time workers and workers in smaller firms are not covered" by the long-term employment system reserved to men employees in big enterprises (Tachibanaki, 2000, p. 11). The coexistence of a core section of protected workers with a relatively large one of lesser paid temporary employees can be found also in the case of Korea, where the recorded incidence of long-term unemployment is minimal. ${ }^{14}$

\section{Insiders and Outsiders}

Let us return to what seems to be the more feasible alternative outside Scandinavia, a trade-off between employment protection and long-term unemployment. As it turns out from the data above the continental and Mediterranean varieties lead to better protection of insiders wishing to maintain their jobs, the Anglo-Saxon liberal market variety of outsiders wishing to find a job, as shown by the much lower average longterm unemployment rates in the latter variety. Putting ourselves in the perspective of the preferences of a representative worker over alternative institutional arrangements, it is by no means clear a priori that even the representative unemployed, if given the choice, would prefer a liberal labour market system, notwithstanding the lower probability to end up as long-term unemployed in the latter case. Indeed, even an unemployed worker may prefer to trade-off the greater difficulty of finding a job now with the shield provided by employment protection once a job is found.

Surprisingly enough, empirical inquiries in the satisfaction associated to different contractual arrangements in different normative setups do not report better feeling of security in case of stronger legal protection of permanent employment contracts. Wherever private employees are less protected, paradoxically, they feel more secure: the empirical studies surveyed by Per Skedinger (2010) "indicate that employees with permanent jobs perceive less security in countries with stricter legislation" (p. 118). In 
Clark and Postel-Vinay (2009, p. 207) "workers feel less secure in countries where jobs are more protected" (with the exception of "permanent public jobs, suggesting that such jobs are perceived to be by and large insulated from labor market fluctuations").

The positive relationship between labour market protection and long-term unemployment that is shown in the tables above can be an obvious explanation of the latter result. In the end greater security in the job does not lead to labour market security, aside from public employment where security in the job is felt to be absolute. ${ }^{15}$

An additional cost from the viewpoint of workers' welfare could be the greater probability of entrapment: as high rates of long-term unemployment tend to be associated with stronger legal protection of permanent employment, to leave a secure, even if unsatisfactory, job in order to look for a more satisfactory one could be too risky a decision. This impairs the allocative function of the labour market and the way in which workers pursue the search for more productive (and better paid), as well as more satisfactory, jobs. ${ }^{16}$

Aside from what appears to be the case in the Scandinavian social-democratic variety, the protection of what is considered to be the weaker side in the employment relationship, the employee, can be to the cost of even weaker actors, the long-term unemployed, or the employed in the secondary labour market, as well as the discouraged workers. At the same time the weakness of the employee position, ceteris paribus, is all the greater the lower the probability of finding a job in case of layoffs and the lower the unemployment benefits (which we do not consider in the present paper). Here the legislator faces trade-offs, which are dealt with in the different varieties of capitalism as well as in the different countries in different ways.

\section{Conclusion}

In the end the choice between the varieties of capitalism, or the wholesale rejection of them, is a matter of individual (and in the aggregate, social) preferences and social choice. But one should not be deluded, as is often the case, by wishful thinking as to the overall consequences of employment protection in the different social and institutional environments. And attention should always be paid to the true nature of the outside options and of the opportunity costs, avoiding what we may call the general nirvana fallacy: if some social arrangement is not perfect it should be rejected because perfection is just around the corner. ${ }^{17}$ Moreover what is relevant is not what alternative is theoretically possible, but what is actually possible.

Turning to current European debates, we may see that concretely the countries making up the European Union belong to different varieties of capitalism, embedded in different historical, cultural and legal traditions. The pretence by some political forces to impose a particular variety at the level of the European Union, in particular with respect to the subject matter of the present paper, the discipline of the labour market, would put the European Union institutions into needless dangerous strains. 


\section{Appendix: Three Popular Economic Fallacies}

Three popular economic fallacies often mar the public discourse about labour law, economic systems, and (un)employment (as well as about any other possible issue of economic policy) .

\section{The fallacy of composition}

If something is good for somebody it is good for the whole class of people to which the person belongs: if a worker's job is protected, and this protection is extended to all the jobs, this turns to the advantage of all the workers.

\section{The lump of labour, and lump of something, fallacy}

The amount of work to be done is given and independent of the provisions of labour law. This fallacy can refer to other objects of discourse, whenever is taken as independent of the relevant legal provisions the number and structure of firms, entrepreneurs, or whatever else. We may call the generalization of the lump of labour fallacy as the general lump of something fallacy. Turning to labour law, its provisions affect the number of jobs not only by varying existing firms' demand of labour (i.e. offers of employment), but also the set of existing firms (i. e. employers) and the supply of entrepreneurship (of those willing to start and to develop a firm and create jobs). To some extent the fallacy of lump of something is based on a confusion between the short and the long run: jobs, firms, entrepreneurs are given at a certain moment of time, but are by no means given in the longer time frame in which legal provisions exert their effects.

A popular instance of the fallacy of lump of labour refers to the idea that if somebody retires, his job is available for somebody else, and thus unemployment can be reduced by lowering the retirement age.

\section{The zero sum fallacy}

If somebody gets something more it means that somebody else gets less, if somebody's lot is improved, somebody else's must be worsened. Thus if employers gain, it means that workers lose, and vice-versa: a wage rise or a legal provision strengthening the bargaining power of trade unions, or enhancing jobs protection goes always to the advantage of workers, even if it leads eventually to bankruptcy and closure of 
the firm or to loss of competitiveness and slowing down of economic growth, higher long-term unemployment or high inflation.

Here too the fallacy concerns the time frame: what looks favourable in the short run may be ruinous in the longer run.

\section{NOTES}

${ }^{1}$ Cf. Calmors and Driffil (1988), Hall and Soskice (2001, p. 20); Amable (2003). Some consideration of the issue can be found in Becker (2009), p. 157.

${ }^{2}$ Cf. Chilosi (2012). Hall and Soskice, following Aoki (1994) rather than pointing to the different ideological and cultural backgrounds as an explanation consider the issue in terms of efficiency, as complementarity between institutions applies when the "presence (or efficiency) of one increases the returns (or efficiency of the other)":

${ }^{3}$ Hall and Soskice concentrate their analysis on the dichotomy between liberal market and coordinated market economies, but also a separate Mediterranean variety is mentioned by them (p. 21).

4 "Unweighted average of version 1 sub-indicators for regular contracts (EPR_v1) and temporary contracts (EPT_vl)", where EPR_v1 is "sub-indicator for dismissal of employees on regular contracts" and EPT_v1 is "sub-indicator for strictness of regulation on temporary contracts" (OECD 2010).

${ }^{5}$ Finland relatively high rates of unemployment may be explained as a consequence of the economic shock of losing Soviet trade after 1990.

${ }^{6}$ Finland relatively high rates of unemployment can be explained as a consequence of the economic shock of losing Soviet trade after 1990.

${ }^{7}$ Cf. Walsh (2002).

${ }^{8}$ According to Boyer 1997 classification, quoted in Amable (2003, p. 83), Austria belongs, together with the Scandinavian countries, to a common social-democratic model. According to Andersen et al. (2007, p.14) not only Austria, but also the Netherlands, another possible outlier, are close to the Scandinavian (or "Nordic") model.

${ }^{9}$ In countries where there is greater job protection the dynamics of the labour market could take the form of greater job to job transfers (Skedinger, 2010, p. 118). To have a dynamic labour market is particularly important for innovative and technological advanced production activities, where risks and rewards are potentially higher and the burden of an almost fixed labour force protected from lay-off much more troublesome.

${ }^{10}$ As well as relatively high rates of economic growth (cf. Anderson et al., 2007, p. 15)

11 "The system is based on social cohesion in the sense of a perception that we are all, in one way or another, in the same boat" (ibidem, p. 65).

${ }^{12}$ For a sober appraisal of the efficacy of active market policies in Sweden see however ibidem p. 115.

${ }^{13}$ On this see in particolar Calmors and Driffil (1988).

${ }^{14}$ Grubb, Lee and Tergeist (2007), p. 12

15 “'Job security', taken literally, applies to security within the present job, while 'labour market security' is a wider concept which also includes the possibility of finding a new job if an employee has been fired" (Skedinger, 2010, p. 113).

${ }^{16}$ As expounded, in particular, by the hedonic theory of wages. On the negative consequences of employment protection on labour mobility and productivity growth see Martin and Scarpetta, 2011. 
${ }^{17}$ For the Nirvana fallacy see Demsetz (1969, p. 1): "The view that now pervades much public policy economics implicitly presents the relevant choice as between an ideal norm and an existing 'imperfect' institutional arrangement. This nirvana approach differs considerably from a comparative institution approach in which the relevant choice is between alternative real institutional arrangements."

\section{REFERENCES}

Amable, B., (2003): The Diversity of Modern Capitalism, Oxford: Oxford Un. Press

Amable, B. (2009): Structural Reforms in Europe and the (In)Coherence of Institutions, Oxford Review of Economic Policy, 25: 17-39

Andersen T. M., Holmström B, Honkapohja S., Korkman S, Söderström H. T., Vartiainen J., (2007): The Nordic Model, Embracing Globalization and Sharing Risks, Helsinki: The Research Institute of the Finnish Economy (ETLA)

Aoki, M., (1994): The Japanese Firm as a System of Attributes: A Survey and Research Agenda, in M. Aoki, R. Dorem The Japanese Firm: Sources of Competitive Strength, Oxford: Clarendon Press: 11-40.

Becker, U., (2009): Open Varieties of Capitalism Continuity, Change and Performances, Basinstoke: Palgrave McMillan

Calmors L., Driffil J., (1988): Bargaining Structure, Corporatism and Macroeconomic Performance, Economic Policy, 6: 13-47

Chilosi, A., (2012): Stakeholder Protection, Varieties of Capitalism, and Long-Term Unemployment, The European Journal of Comparative Economics, 9: 197-228

Clark A., Postel-Vinay F., (2009): Job Security and Job Protection, Oxford Economic Papers, 61: 207-239

Demsetz, H., (1969): Information and Efficiency: Another Viewpoint, Journal of Law and Economics, 12: 1-22

Freeman, R. B., (1988): Labour Market Institutions and Economic Performance, Economic Policy, 3: 63-80. Stable URL: http://www.jstor.org/stable/1344504

Grubb, D., J. Lee, Tergeist, P., (2007): Addressing Labour Market Duality in Korea, OECD Social, Employment and Migration Working Papers, No. 61, http://dx.doi.org/10.1787/058184274204

Hall P.A., Soskice D., (2001): Introduction, in P.A. Hall., D. Soskice (eds.), Varieties of Capitalism, Oxford: Oxford University Press

ILO, (2011): Key Indicators of the Labour Market (KILM), Seventh Edition, http://www.ilo.org/ empelm/pubs/WCMS_114060/lang--en/index.htm

Martin, J., Scarpetta, P., (2011): 'Setting It Right: Employment Protection, Labour Reallocation and Productivity', IZA Policy Paper No. 27, http://ftp.iza.org/pp27.pdf

OECD, (2010): Indicators on Employment Protection - annual time series data 1985-2008, Version 2 - updated 24-09-2010, www.oecd.org/dataoecd/62/38/42773608.xls

Skedinger P., (2010): Employment Protection Legislation: Evolution, Effects, Winners and Losers, Cheltenham, Elgar

Tachibanaki T., Taki A. (2000): Capital and Labour in Japan: the Functions of Two Actor Markets, Abingdon: Routledge

Walsh, B., (2002): When unemployment disappears: Ireland in the 1990s, UCD Centre for Economic Research Working Paper Series WP02/29, University College Dublin. School of Economics, http://www.ucd.ie/economics/research/papers/2002/WP02.29.pdf 